\title{
Multifaceted Religious Feminism - The Case of Modern Orthodox Feminists in Israel
}

\author{
Galit Yanay-Ventura
}

Department of Human Services, Yezreel Valley College, Israel

Copyright $\bigcirc 2016$ by authors, all rights reserved. Authors agree that this article remains permanently open access under the terms of the Creative Commons Attribution License 4.0 International License

\begin{abstract}
This article deals with orthodox feminists in Israel. Its aim is to study how women create a religious feminist identity and attach to orthodox feminism as a shared space. For this purpose I interviewed 44 women, all of whom declared openly that they regard themselves as orthodox feminists. The interviews dealt with the creation of a religious feminist identity and the conceptions, beliefs, customs and soul searching created by this identity. Five different narratives are presented: the traditional, retiring, interpreter, juggler and rabbinical. Every one of them provides a different world view and a unique answer to the issue of how to be both religious and a feminist. These narratives are not binary (feminism versus religion, feminism or religion) but rather an open-ended interweaving between feminism and religion that produces religious feminism without a hyphen.
\end{abstract}

Keywords Religious Feminism, Religious Subjectivities, Jewish Feminism, Judith Butler, Qualitative Research, Narrative Analysis

\section{Introduction}

A large number of feminist writings, especially in the first period of radical feminism - regarded religion as the dominant area of inequality between the sexes. Many writings focused on the idea of discrimination of women in religion and stressed the conflict between feminism and religious practice (1). This attitude was the cornerstone of studies in religious feminism and aroused a number of questions for theoretical discussion: what are the reasons for a woman's choice to be both religious and feminist and how do religious feminists feel when confronted with the gaps between the two discourses? Do they regard religion and feminism as contrasting practices or not? How do they manage to contain what their secular feminist colleagues regard as conflicting?

As for the creation of the religious feminine identity, several typologies were developed aiming to map the various efforts to bridge the gap between them, as well as different kinds of negotiations. These bridging efforts, designed to create an identity based on dimensions appearing to conflict with each other, stressed attempts at uniting the two discourses: adapting feminism to religion (by reinterpretation of the concept of feminism), adapting religion to feminism (by reinterpretation of religion), and separation between feminism and religion (without any attempts at interpretation or bridging between the categories)(2-9). This conception of transformation was also expressed in expectations for change: expectations for radical changes in feminism; expectations for a radical change in religion; expectations for a restricted change, usually in religion, with the hope for changes in the future (10-12). For example, Elaine Ecklund described how women who reinterpreted feminism, located and sorted out meanings that could help them preserve their religion. When disparities appeared between the two discourses, they defined feminism from anew in a way that would suit the religious structure. On the other hand, when they reinterpreted religion, they tended to attribute different weight to religious symbols, neglecting discriminating symbols and intensifying egalitarian symbols by emphasizing them over and above other symbols. Finally, in the third type based on a strategy of separation, the women created two individual identities neither threatened nor defendant on each other. They accepted the gaps between the identities as unavoidable and chose not to identify particularly with one of them (5). An examination of the different types of bridging shows that the creating of a religious feminist identity is a process of adaptation between two sets of values: adopting the feminist perspective and changing religion accordingly, or adopting the religious perspective and changing feminism accordingly. The researchers adopt a theoretical point of view stating that in states of conflict, the dominant identity resolves the conflict by granting seniority to the dominant identity at the expense of the other identities (13).This approach is prominent in the writings of researchers describing women who abandoned their religion on account of their feminist beliefs $(11,14,15)$, or, otherwise, rejected feminism in favor of their religious identity $(16,17)$. Here too, the predominant 
conception is that the dominant identity motivates the change of the secondary identity in a move towards the dominant identity.

According to a different approach, states of conflict actually cause the dominant identity to become a moderating factor and enable the promotion of a secondary identity. Thus the feminist view of injustice might welcome a different view of religion that could enable a resolution of the two types of discrimination together (18). The meaning of this is that as soon as the dialectic process between the categories has begun, the boundaries between them become blurred to a point where it is difficult to decide which is the dominant and which - the secondary. Actually, hybrid models described the creation of a religious feminine identity as an act of mutual transformation (19-22). Dafour, who studied Jewish religious feminism, described this transformation as a "filter" in which the discourses of religion and feminism are processed, and some of the values and practices are accepted while others are rejected, on the basis of personal standards (filters). This kind of information processing derives from the religious, personal and spiritual needs of the women. She showed that when a woman has unique religious needs, the "religious membrane" filters conflicting contents of feminism and vice versa (10). Dufour's contribution by means of the transformation model that she developed in the study of the preliminary process of bridging, is the examination of the reasons, needs (or standards) that determine the kind of shifting processes. This procedure, as described by Dufour, does not enable the creation of unified bridging processes for different women, because different needs produce "unique filters" that require us to accept differentiation and variation in the strategies employed in the creation of identities. Nevertheless, Dufour, when describing the bridging model that she developed, used representations reflecting adaptation and adjustment: conformism (responding to religion), transformism (responding to feminism) and reformism (limited response to religion with the expectation of change in the future). This wording also conveys a one-directional movement toward feminism or religion and leads to a conception of assimilation of the one in the other. The question is how to describe the creation of a religious feminine identity that is not destructive to one of these categories? Why is it that despite the hybrid character of these models, most of the representations remain homogeneous with a one-directional movement? Similar representations also appear in research dealing with religious feminist practice. Orit Avishay (23), reviewing the theoretical literature, presents three prevalent strategies of women practicing religion and feminism: women responding to religious practice and empowered by it $(16,17,24-27)$, women who do not respond to religious practice and reject it $(28,29)$ and women responding partially to these practices based on strategic considerations (30-33). The partial response differs from the first two responses and expresses a two-directional dialectic: areas responding to religion and areas responding to feminism and vice versa, when the differential responses are based on personal, public and (other) family considerations. The partial response wants to abandon the binary concept of responding or not responding, and to accept the many unique and inconsistent patterns chosen by women $(23,27,32,34)$.

The conception abandoning the binary approach of feminism-religion/responding-not responding is also prevalent among researchers emphasizing the pattern of separation of identities (6-9). In this pattern, the creation of a religious feminist identity is made possible, by means of separating the categories of identity, and refraining from establishing an essential connection between them. This model differs from all the other bridging attempts presented so far, in that it does not endorse a movement (dominant or partial) between feminism and religion. This means, according to the concept of separation, that women can be both religious and feminist in two separate niches of their identity, without one of them influencing or being influenced by the other. For example, as shown by Gallagher, Smith and Manning $(7,8)$, they can practice equality with their partners in everyday life, but accept the principle of gender-hierarchy in the synagogue. They can pursue a career based on achievement, relying on the principle of equality, and agree that in religious life gender blocks their access to religious leadership roles. The theoretical question arising in this context is how can religious women create a feminist identity while at the same time renouncing their feminist orientation based on equality, in religious life? The researchers explain that the connection between feminism and religion is not necessarily dialectical. The strategy of separation symbolizes the fact that religion does not necessarily affect the feminist identity. The disharmony created between the rhetoric aspect (preserving the symbolic boundaries in religion) and the practical aspect (practicing equality in the work-place and in private life), helps them to cope with the conflict imposed on them - to integrate in the larger society while at the same time maintaining a distance from it $(7,35)$.

Judith Butler, in her book 'Gender Trouble', calls for a new way of looking at sex and gender that may contribute to a renewed understanding the dichotomy between feminism and religion as well. In contrast to the gender oriented binary concept - masculine/feminine, Butler maintains that gender should be conceived as elastic, fluid and changeable. The agency, is never clearly male or female, but in a state of fluidity with an identity that all the time constitutive social and contextual. Butler makes a distinction between the way we behave at time and different situation and goes against what she calls the illusion of 'core gender identity' as if there was a constant inner essence that can be described as male or female. Instead, she calls us to break down the way our grammar and manner of thinking obviously based on the logic of this core. Thus, for instance, we tend to believe that core gender identity causes a woman to wear a dress whereas there could be manifold reasons for such a decision. We mistake, because gender norms refine the choices and the performances appear to be naturally associated to this core. Instead, discontinuity in our performances is part of creating a new identity - hybrid, opposes to gender coercion and seek 
to re-mark of identity and increasing the number of gender options in the dominant discourse. Butler's work may contribute to the understanding of religious feminist identity. Instead of regarding religious feminist identity from a point of view of feminism or religion, we should regard it as an identity moving constantly into and away, within and outside feminism and religion. This means that we should not envisage one dominant way, or even two or three way of mediations between religion and feminism, but devise a way of manifold options and directions of thinking.

Thus, in the following article, on the basis of Butler's work, I suggest a new way of reading the process of creating a new religious feminist identity, as manifest in the behavior of modern Israeli orthodox women whom I interviewed. As I shell show, it is impossible to understand the procedure of creating an identity by adaptation of religion to feminism or vice versa. The issue of seniority of one of the identities - the feminist or the religious - is constantly shifting between the themes and changing focus. It was also impossible to understand the religious feminist identity by the separation of the categories religion and feminism. It was hard to point the pattern where the category of religion ends and the category of feminism begins - for example, does the wish to divide the blessing on Sabbath eve between the woman and her husband, derive from the feminist ideology of the equality of the sexes, or rather from the religious need to bless on Sabbath eve? It is hard to follow the internal dialectic because it is dynamic and changing, containing several foci and themes, and because the discussion of them is lively, continuous, dependent on context and not dogmatic. In order to understand the dialectic process of creating a new identity I recommend reading the religious feminist identity without hyphens, but as a manifestation of a dialectic process which is neither dichotomous, nor one-directional or two-directional, but contains many connections and dimensions of a subjective and intimate nature. It is not dependent on the dichotomy between feminism and religion, but is conducted in a state of constant translation of the existing reality in which both religion and feminism constitute a means of action and a decision to act. The removal of the hyphen, therefore, is not a linguistic or semantic change. This perspective aspires to read the dynamism of the religious feminine identity as a hybrid process of creation not necessarily understood. The wider significance of this process is that the religious feminine identity is neither a mechanical connection, nor a combination of feminism and religion; the dialectic between feminism and religion expands the categories and creates a new theoretical category which is both feministic and religious as a shared space.

\section{Modern Orthodox Feminism in Israel}

Modern orthodoxy in Israel is a stream within Orthodox Judaism that espouses the integration of halakhic Judaism and the ways of life of the modern world. Modern orthodoxy is common within Jewish communities in the Western world, mainly in the United States and Israel (36). In Israel, modern orthodoxy is a spiritual and intellectual stream that tries to combine nationalism, modernism and religion. This combination, called "Torah and work," includes in parallel the requirements of living an orthodox religious life, productive labor, participating in the nation's defense, acquiring an education, and personal involvement in the secular society at large (37). In contradiction to the assumption that ultra-religious societies preserve their religiousness by maintaining a separation between themselves and modern society $(4,38-40)$, modern orthodoxy is a test case for a group trying to preserve its religiousness within secular modern life.

Among them, orthodox feminist is a unique group of women who have sought to reinstate certain customs from which women were originally exempted but which are permitted by the Halakha (Jewish law) (41). These women want to study the Torah and the Talmud in chavruta (study pairs) like their male counterparts in the traditional Bet Midrash (study house) (42). Studies of Orthodox Jewish women have mainly explored the ways women embrace practices, rituals, and commitments, such as the mitzvah (commandment) of tzitzit (a four-cornered fringed garment), praying wrapped in a tallit $(43,44)$, the prayer and naming celebration on the birth of a daughter (45), reciting the Kaddish (the mourner's prayer) (46), or delivering a eulogy during or after a funeral (47). Being feminists, they take upon themselves an additional religious onus that is generally not required of women, which brings them closer to and strengthens their belief. Being orthodox, they accept the Halakha (Jewish law) in its entirety, exalt it as the word of God, and accept, by choice, the orthodox restrictions. From the theoretical aspect, these orthodox feminists neither trying to contend (with more or less success individually) with the binary dichotomy of modern/secular versus religious/traditional but also refuse to accept the binary opposition of feminism and religion in the sense that feminism represents freedom and religiousness the restriction of personal freedom.

\section{Methodology}

The data collection focused on women who are both feminists and religious orthodox members of the "Kolech" ("your voice" in English) - an organization of declared feminist orientation of the modern orthodox community in Israel ${ }^{\mathrm{i}}$. Forty-four women participated in the study during the years 2007-2008. The interviewees were between the ages of 30-73; most are heterosexual, married women who hold academic degrees and were born in Israel. Of the Israeli-born, the majority are of European origin (Ashkenazi), with only a minority from Arab countries (Mizrahi). Women in Kolech are aware of this disparity, discuss it in their conferences, and work towards raising the membership of Mizrahi women (48). Kolech remains, however, a predominantly Ashkenazi 
organization.

The data was collected through by means of the narrative interview. This interview is based on open ended questions inviting the interviewees to speak about themselves and their lives (49). This method is especially suitable for the goal of this research because of its advantage in exposing the identity of the individual, his attitudes, approaches, the conflicts experienced and the characteristics of his environment. The vagueness of the narrative encourages processes of structuring of the narrative, and this means that the narrative is an act of agency (50).

The interviews focused on how their religious feminism evolved with reference to the various events, people, dilemmas, experiences, fights, values, life rituals and conceptions related to them. In this part I adopted Gabriela Rosenthal's approach (51), remaining passive as far as possible and restricting my role to asking the opening question. This approach requires the interviewer not to interrupt the course of the life story till its end, in order to avoid any interference in the structuring of the narrative. Any leading question, even for purposes of clarification, according to this approach, severs the continuation of the train of thought and detaches the respondent from his natural narrative. Therefore, I wrote down questions in my notebook in the course of the interview and asked them at the end of the entire story of respondent, before moving on to the second part of the interview. Thus I obtained various stories from the interviewed including the passage of events and insights concerning the evolution of their religious feminist identity and the way in which they applied it in different walks of life. In the second part of the interview I focused on feminist and religious practices and the interconnections. In particular, I asked about their implementation of religious practices, such as reciting the Friday evening Kiddush, breaking the Sabbath loaf, wearing tefillin (phylacteries), wearing a tallit (prayer shawl), covering the face when lightening the Sabbath candles, reciting the Kaddish, and participating in prayer groups. I asked whether, when, why, and how they perform each of these practices, and if not, why not.

All of the interviews were conducted by the author of this paper. The analysis of the data was done according to the grounded theory (52) without preliminary theoretical models. This assumption suited the purpose of the research, namely to understand the basis of religious feminism from the point of view of the women ${ }^{\text {ii }}$. Five feminist narratives emerged: "traditional", "resigned", "interpreter" "juggler" and "rabbinical". Every one of them represents a different agenda and a different interpretation of religious feminism. All the names are fictitious; the quotations, the language of the interviewed are theirs and the interpretations are mine.

\section{The Traditionalist}

The traditionalist presents traditional images of men and women and resolves the dilemmas arising regarding religious feminism from what is apparently identification with the orthodox point of view. She accepts the orthodox point of view with regard to the order of gender and actually enjoys the traditional order of things internalized by her. Therefore it sometimes appears that the fact that the traditionalist chooses tradition is actually a renunciation of feminism, but avoiding from reading the narratives through a movement between feminism and orthodoxy appears that the traditionalist choice of traditional feminism is strongly connected to her love of the orthodox tradition as it is, despite the distortions that she finds in it.

Here is Rachel,

To be a feminist according to religious law.....makes it almost impossible to be a hundred percent feminist and a hundred percent observant according to Jewish religious law. I feel that I am living in a certain kind of duality, and friends of mine, who are religious feminists, also live like that. We talk a lot about that. It is not simple and connected to emotions...for us religion is something very warm... a very good experience that we grew up with...so to go too far with feminism means to give up something very warm and embracing. You don't always want to break up with everything, even when you know that it is... and following this duality...in the synagogue, for instance, sitting behind a curtain behind a partition, to look at what is going on among the men while you are just someone looking at it from the outside. Something like that, if it had happened in the outside world we would react immediately (laughing aloud) and I am part of this, not only because I am obedient but because I really want it. Why? Because it pleases me, it really does. If I go to a synagogue where there is complete equality, I feel alienated, I feel alienated because I did not grow up with this, it is so strange to me. There is something about religion that makes you feel rocked, reminds you of your childhood and you feel good about it and you don 't want to destroy everything even if it does not fit your values completely. On the emotional level, to listen to a woman reading the Torah, in my opinion, is as if...it is not real...it is as if...I don't know.... when I hear a woman reading the Torah, emotionally it makes me feel like, how, on earth, did this happen to us?

Rachel talks at length about what religious feminism means to her and describes it as a complex conception associated with manifold duality. She talks about the injustice in the synagogue; the fact that women are relegated to the women's section cries out as injustice. In any other situation she would have rebelled against it, but still in religious life she feels alienated when she is in the egalitarian synagogue. The new division of roles creates a feeling of internal chaos and alienation. She feels that tradition has something embracing about it. It contains unity, security and a memory of childhood that she is reluctant to give up. I called Rachel and the women like her traditionalist because the religious feminism that they created is strongly 
connected to their love of the orthodox tradition as it is, despite the distortions. The traditionalist adopted a similar attitude towards the renewal of rituals by women. On every topic they were not prepared to change the customs and felt lost when anything in the natural order of things was changed. Therefore some would say that the traditionalists are not feminist enough that their choice of the orthodox tradition is a renunciation of feminism. One could possibly argue that Rachel adapt feminism to religion, namely she adopts the orthodox perspective and interprets feminism in a way that is adaptable to tradition. I do not accept this argument. Rachel emphasized the injustice inherent in the order of gender, she does not ignore the conflict or deny it by means of rhetorical harassing thus showing that she does not adopt the religious point of view. In her rhetoric spending time in the egalitarian ritual of prayer (Minyan) is unbearable. The fact that Rachel actually went to an egalitarian Minyan challenges the common explanation. This means that her feminist orientation led her to make the experiment, but what she experienced made her change her mind. When she came to the egalitarian Minyan, she felt revolted by the change as if she had lost something dear to her. This experience taught her how she preferred to live as a religious feminist even if it did not "agree a hundred percent with her values". It makes sense that the orthodox history of the women affects their feminist orientation, but it does not necessarily result a 'collapse' of her feminist identity. Possibly the experience of an orthodox woman changes the nature of feminism in religious contexts and of religion in feminist contexts. Dropping the "hyphen" as I recommend, suggests not to place the religious feminists on a scale between religion and feminism and but rather to interpret the different identities without separating them, and to regard them as a dialectical interweaving of life in the shadow of "both the one and the other".

\section{The Resigned}

The resigned type represents an extremely critical attitude of religious feminism directed towards the orthodox community. Contrary to the traditional type, whose religious feminism focused on the orthodox tradition, the resigned type focused on the orthodox community. In her opinion, the rules of dress, modesty and separation of the sexes are not part and parcel of the essence of religion, but an androcentric reflection of society in anachronistic periods from a cultural point of view. She does not understand why members of the orthodox community continue to adopt the same anachronistic rules even though they are aware of the fact that these rules discriminate one sex in regard to the other. According to her interpretation, their response is the result of fear, submission to rabbinical rhetoric and a sign of the lack of religious rationality that has infiltrated the orthodox community. Therefore, the resigned chooses a mechanism of distancing: she navigates between alienation and closeness, revolt and participation, belonging and resigning, in order to find the right boundaries for her.

Here is what Sari has to say:
The cover...is like that of the Taliban, exactly in the same place, only instead of a black veil covering the body, ours is a colored veil, friendly to the environment. They can change the color, the shape and the....but it sits in the same place, in the place of modesty, in the place of "she is respected as the daughter of the king inside her home", you are the man's property, ....you must be modest so as not to arouse him...everything is geared to the man's feelings and emotions and how he will feel about it. The more he feels protected, the more you must cover yourself.

Sari demonstrates intense anger directed toward the idea that a woman is required to carry the burden of modesty that does not involve responsibility for herself, but rather for the man`s benefit, "so as not to arouse him". We can see radicalization in her comparing the head coverage to a colored veil and also in the term Taliban. She does not spare the women either and says: "They can change the color and the shape..."when she uses this term, the question arises: who are the women she meant when she said "they", and is there an internal division among orthodox women between those who agree to cover their heads and those who don't? If there is such a division, what does it signify? Here it becomes evident that the religious feminism of the resigned is based on the creation of new reference groups inside the orthodox community that enable them to be both together and separate; to belong but to be unique in the orthodox community.

Here is Nili, which I also classified as belonging to the resigned type:

When I am among my secular friends at work, I am really ashamed of the status of a religious woman. Do you understand? When my secular friends from work arrange a Bar Mizva for their sons, they will say, whoever celebrates the Bar Mizva according to religious precepts...let us say, the boy ascends to the Torah, she will say: it is really a shame that the boy ascends to the Torah and I am sitting behind the curtain at such a distance, now I understand them. I mean, I... now I can see this and I say 'walla, this is...really a shame'. It does not fit to my rationale; I feel that I want to die at this moment. I am standing with my sisters and I say to them: We can see but we are invisible? When you read the stories running in the internet, on television, about all the women who were refused to obtain a divorce, you... you are ashamed. I mean I am ashamed that I am Jewish in this context, and even more ashamed of being religious, there is a discrepancy between my rationale and ... as if to say where am I and where is all this. I want to get rid of this place for good.

In Nili`s case we can see the difficulty in coming to terms with the accepted values in the orthodox community. 'It's a shame', she says, emphasizing the threat and alienation created by the conflict between her opinions and the accepted practices in her community. Nili, too, creates new 
reference groups and in her case they are the outside secular groups. This is a very interesting point in the interviews. I saw that apart from inter-personal differences, some of the women share the same components. They reacted in the same way to the discrepancies that arose, provided shared explanations, weakened and strengthened similar motives. Among the resigned the main conflict is not between feminism and religion, but between feminism and the members of the community, who, in their opinion, represent Jewish religion wrongly. Thus the main pattern of 'resignation' is - abandoning the past reference groups and adopting 'others'. Actually, with regard to religious feminist practices, the resigned does not endorse a renewal of the observances from which women were originally exempted. As a result of the anger inherent in her attitude, she does not experience spirituality when practicing religious rituals, and believes that most of them are more of a custom than part and parcel of Jewish religious law. We can also see that both the traditionalists and the resigned do not renew religious rituals from two very different positions in religious feminism.

Therefore, should we consider the resigned as alienated from religion and preferring feminism? Here, too, such an interpretation would be a mistake. The paradox characterizes the resigned, which, despite her extremely critical attitude, is not really resigned, nor has she torn all the threads connecting her to the community. She abhors the educational institutions but sends her children exclusively to them. She looks for solutions inside, such as "Pelech", (a religious feminist educational institution), but if they are not available she sends them, despite her criticism, to be educated in the community. In the end, for her too, resignation is not an option. In order to safeguard the right boundaries, she navigates between alienation and closeness, abhorrence and partnership, belonging and resigning. Her solution is temporal and elliptic without a center or a focus.

\section{The Interpreter}

The interpreter is a scholarly figure who studies the dialectic between feminism and religion, mainly by way of challenging the religious writings. In her opinion, the biblical texts are deeply inspiring, daring and wise and therefore they arouse anger and despair in her whenever she encounters misogynous writings against women. She experiences a severe conflict: how could the sages of the Mishna and the Talmud treat women so disgracefully? Why do they reject the presence of women and what do their mistaken representations teach us about them as the adjudicators of generations? Here, too, ideology is related to the core of the conflict: the interpreter decides to challenge whatever appears in the biblical texts. She regards them as multi-faceted and views them critically. The main issue of interpretive feminism is to acknowledge the conflict, to reconcile oneself to a religion that is not perfect, to see that sometimes a contradiction exists between feminism and religion and to accept it. Her attitude is conciliatory toward religion and she strives to find a place for women in the religious precepts, the synagogue, the Torah and the prayers, regarding the community as a complex entity and acknowledging the fine balances required. She regards her ability to act as a leverage of feminism in the orthodox community, as a mission, and attaches great importance to change in the community from the inside.

I would like to give you several examples in order to try to explain that every single moment can possibly be regarded as if it can contain everything. How do I give it the power to contain something greater than itself, namely not to reject a part but rather to include it... it is not a cake that if men get it, then women cannot have it. There is a chance of doing something that will include everything. I am looking for the places where I will not have to reject one image of God from the image internalized in me, which is a complex image, someone like the God of the Rambam, who has no body and no form, and who is also the God of the sages of the Mishna and the Talmud, one who is the commandment of the prophet Elijah and the like. I am looking for the places that I consider the most worthy, the ones where it is possible to believe in to be both.

Here we can see the position of the interpreter. For her, religious feminism is an interpretive process aiming to achieve two points of view. She wants to avoid a decision favoring the one at the expense of the other (feminism or religion) and searches for places to understand and read the biblical text as 'both the one and the other' - both according to the orthodox perspective without changing the text sanctified by it, and also in accordance with the feminist perspective in the center of which stands the woman and her world. Here she expresses the integrated feminism that does not reject the existing structure, and this pertains to the image of God: there is the image of the prophet Elijah and that of the sages of the Mishna and the Talmud with the black locks, and she regards this as proof that God's image is in the eye of the believer and is not related to gender.

Let us take another example of interpretation. I have read the story of the Parting of the Red Sea in Ilana Paredes's text we are used to think of the parting as one of the ten plagues. This militant God 'by means of a strong hand and a raised arm 'and suddenly she says: the Exodus from Egypt is the story of people who were shut inside their house. The opening of the house was blocked by blood and at this very moment, when danger threatened the first born, the opening that was blocked and seeped in blood, burst open. They left the house and passed through a narrow passage surrounded by water on all sides. They moved to the other side and there everything was open, and they became a nation. This is like the picture of the uterus and like that of a birth. It is not a homiletic interpretation but a simple one. It is not apologetic at all. It takes the side of the God of the 'strong hand...' and that of the war against the Egyptians, they drowned and that was that...the two 
narratives can be seen together, the one and the other, and contain each other. This, for me, is the optimal model; these are the interpretations that I am looking for.

Tamar continued to search for a new way of thinking. She said that she suddenly found consolation. Ilana Paredes's interpretation empowered her. In both narratives danger threatened the first born and in both they were redeemed and the sons of Israel became a nation. The difference between them lies in the interpreter's imagination, in her point of view and in the ways of achieving the goal: in the one it is the parting of the Red Sea as a battle, and in the other it is the release from the house and birth. The second interpretation suits her imagination better. From this intimate place, the text again becomes the source of nursing. Tamar's words reinforced my conviction of the importance of avoiding the separation of the categories of feminism and religion. In the study of dialectic it is difficult to decide whether the interpretation of the exodus from Egypt is feminist or religious and it would be correct to describe it as a feminist religious interpretation. This means that in order to understand Tamar's feminist religious identity, we should read it as they do - feminist and religious sharing the same space.

\section{The Rabbinical}

The rabbinical is the most radical figure in religious feminism without a hyphen. Usually she is a young woman, a learned person and a scholar (Talmid Chacham). She has acquired higher education in the religious texts (Talmud) (in a women's college) and continued to study for an advanced degree in Talmud. In the course of her studies she experienced empowerment and discovered Jewish orthodoxy from anew. Her vast knowledge along with her analytical capacity, have provided her with new tools for thinking: she understands the ways and methods of researching whether a certain thing is permitted or forbidden according to religious law, and is not deterred by painstaking search or learning. She gives learned answers to any questions along with a long list of sources and quotations supporting her position. Actually, here, the significant process begins for her. She becomes 'her own rabbi'. Although she is aware of the restrictions to which orthodoxy subjects her, among them the one preventing her from becoming a rabbi, she regards herself, despite her resignation, as no less knowledgeable and suitable for the task. She develops an ambivalent attitude towards the rabbis and examines carefully whether their ruling derives from direct access to the sources or from concern for the meta- Halacha (sociology and ethics). She becomes intolerant towards the 'sociological'approach (connected to the future of the community) and demands that the authorities present religious law as it is, much more positive to equality for women.

I don't make interpretations and don't go to problematic sources in need of interpretation. I am quoting a source that writes that a woman can do this. This is the beautiful thing about Judaism: We have generations of rabbis and adjudicators ever since the Talmudic era who had the time, and it was the only thing they did from morning till night and therefore they asked all the questions on earth: can a deaf person do it? Can a child do it? So a woman can also do it. Everything was considered from the perspective of the woman, a pure theoretical discussion. [....] We are not afraid anymore and I am saying this very carefully, there are those who accept it and those who don't, but we have decided that we no longer need this authority to give us approval for these things, because we examine the same sources that you do, all of us obtain our food from the same source. I don't go round inventing new sources or say that religious law is 'a developing process', I go through the same process, but my world view is different from yours, so I say - I am sorry, but because my world view is different, I will never be able to regard the woman solely as an object, I want her to be a subject.

Since this is the situation, the women in this group strive to attain complete equality, as far as possible. They persevere in their studies and prayers; some of them lay the phylacteries or wear skull caps. They usually have egalitarian relations with their husbands, sharing the Sabbath prayers, the religious festivities, the blessing on Friday night and the cutting of the Chala. Their practices encounter a great deal of criticism and resentment on the part of many believers who regard their activities as an impracticable stretching of the boundaries of Orthodoxy. Therefore, there are those who say that she is the most feminist figure among the interviewees, and that the radical changes she produces, distance her from religion and draw her nearer to secular feminism. Here, too, I disagree to this representation that tends to regard the complex reality in which women live, in terms of a binaric relationship. Here, too it is difficult to point out when the feminist identity begins to determine the lifestyle and when religion ceases to do so.

Here is how Pnina addresses this dilemma:

I take these things seriously, I mean all my life I never expected somebody else to do things for me. I take responsibility for my life, for my choices... and, also, in the sphere of religious precepts, I do not want somebody else to observe them instead of me all the time. Of the high priest it was said that he atones for himself and for his home. His home is his wife. He prays for her. No one prays for me. This does not touch me one little bit. He prays for himself and this does not help me. I am sure that if he feels better about himself, more harmonious and connected, it will also affect me. If, for instance somebody would tell me that it is enough if he goes for psychological treatment and it will affect you, it surely will affect me, but not in the way I want it to. 
Pnina explains her motivation. She wants us to acknowledge both her religious and her feminine needs. For her feminist and religious identities are two sides of the same thing; she wants to bless, to pray or to cut the Chala (Friday bread) out of a need for spiritual and personal elevation as a person enjoying equal rights in religion and in society. In other words, for her and for other rabbinical women I have met, there is no difference between the significance of being a religious woman and of being a feminist. For them the feminist identity and the religious identity are one and the same.

\section{The Juggler}

Finally, some of the women presented their thoughts and actions as if they were jugglers. These women were extremely sophisticated. Sometimes they sounded like conservatives, and sometimes - like radicals, and they knew how to switch from one position to another in the most amazing and harmonious way. Their attitudes were not normative and they were usually expressed with a wink. Obviously they had a profound understanding of the religious society in which they lived. They, too, were scholars, proficient in the Talmud and teaching it to women. They were dressed modestly and strict in observance of the religious precepts. In the middle of all this they initiated feminist processes in a quiet way so as not to arouse suspicion of dissent.

Here what Ester told me at the beginning of the interview:

"Until the men will not share my task, I will not do theirs"

Ester started the interview with a wink. Like other interviewees, she referred to the fact that women are not obliged to observe the precepts valid at a fixed time. She tried to explain her attitude as to whether she supports or does not support women's participation in the renewal of the religious precepts. At first what she said sounded conservative. She argued that she is not interested in the renewal of observance for women, a basic tenet of religious feminism, but her reasoning was radical - she does not support a one-sided reversal of roles by women, and demands equality as a pre-condition to the observance of religious precepts. She does not oppose the entry of women into men's roles but she does not approve of it either. Her pattern of activity is cynical.

And she continued:

When they changed the curtains in the men s section (in the synagogue), they left the old ones in the women's section, and I am not talking about poor people. The pretext was that there was not enough material, so what? they can buy some more. It happened in summer and I asked my husband to tell the manager of the synagogue that if they don't change the curtains in the women's section by Rosh Hashana (New Year), the rabbi 's wife will not attend, and it helped...
In this case Ester takes a firm stand. She announces that she will not come to the synagogue from Rosh Hashana onward as long as the curtains in the women's section are not changed. She chooses a frontal response and persuades her husband to take her side. She exposes the arbitrariness in the way the synagogue managers treat women in the synagogue and during prayers: the changes between the positions she adopted, surprised me: I asked her what her attitude was in general and how she conducts herself differently according to the issues at stake.

\section{My attitude in many areas is to regard things differently and to start... for instance, for about thirty years I have been teaching lessons in Talmud. It started when ...there were some women...I had the necessary background and the women wanted a lesson, they wanted to study the Talmud. At first we chose a man. At that time for a man to understand the mentality of women beginners a... so the saying is 'where there is no man, try to be a human being', but this attitude was not accepted at the time and I didn 't advertise it anywhere...but I said that if there are three women who wanted to study, you have a teacher and you can bring your friends. I calculated that if the wife of the rabbi teaches a lesson in Talmud for ten years, it is not forbidden (laughs). Now there is a different attitude and it is the right one, and that is, if you have not advertised, you have not done anything.}

Ester tells me of her approach to action. She goes against public opinion and teaches women Talmud in her house. She believes that she has to teach the women, and that is not necessarily 'feminism ' but first of all 'to be a human being', at least this is the way she expresses it. She is aware of her standing as the rabbi 's wife and a radical, and decides not to advertise the lesson, but to open her house to women who want to learn and thinks that 'if the rabbi`s wife has been teaching' it will become a norm. This means that Ester stretches out her arms flexibly and according to the constellation that she manages to create. She is acting outside and inside religion, inside and outside feminism, always according to the threat of disruption confronting her. From a primary point of view, her dialectic seems inconsistent, the changes between her attitudes make you wonder 'what is her overall opinion and why does she adopt 'zigzag' attitudes on various issues? I called her and other women like her, jugglers on account of their capacity to examine everything according to the situation as if they were not totally committed, and at the same time to act as if they were. Therefore, although all the women interviewed displayed a multi-faceted approach, the dialectic of the juggler, is the more tricky and emphasizes the conception that the dialectic in the religious feminist attitude is complex, flexible and branching out in many directions. 


\section{Discussion}

This paper attempts to understand the way by which feminist women create their identity as religious and feminists. The paper is connected to a growing research literature dealing with the dialectic between feminism and religion and the way in which women negotiates their identity between the two discourses. The theoretical contribution of the paper is the suggestion to avoid a definition of the religious feminist identity as a strategy of bridging the gap between feminism and religion (by using various kinds of compatibility between the two) or by separating the categories of religion and feminism in one's personal identity. Instead, we suggest that the religious feminist identity should be written without a hyphen - as an expression of a new identity which is not dichotomous (feminism as opposed to religion/feminism or religion), one-directional or two-directional, but as containing many intimate and subjective connections and dimensions, constantly interacting with existential reality. The removal of the hyphen, is not a linguistic or semantic change. This perspective aspires to read the dynamism of the religious feminine identity as a hybrid process, not necessarily understood. The dialectic between feminism and religion expands the categories and creates a new theoretical category which is both feministic and religious as a shared space.

Thus, the 'traditional' woman who seemed the most conservative of them all, decided to adopt this strategy because the preferred the orthodox tradition despite the inherent discrimination of women. She did not deny the exclusion of women in the traditional orthodox synagogue, but her experience in the egalitarian synagogue left her with a feeling of internal chaos and the loss of home, history and roots which were important for her. This might be regarded as an adoption of the traditional point of view or an adaptation of her feminist identity to tradition. Such an interpretation considers the orthodox identification as the dominant element in the woman's identity that requires her to accept the traditional order of things. Such an interpretation, in the light of my research, is incorrect. The 'traditional does not identify with the place of women in religion and nor does she justify the traditional exclusion of women. In her narrative the new religious practice is strange to her. Because the traditional order, despite its shortcomings, provides in her opinion, well-being for both genders, the religious feminism which she strives to achieve, does not imply a complete revision of the traditional order. As a rule, the hyphen, that we propose to omit from the religious feminist identity, means that the women should not be placed on a scale (continuum) between religion and feminism. Instead we can say that religious feminist identity is a dialectic integration of the one and the other together. Even for the 'resigned' woman, in spite of her feminist criticism about the orthodox community as anachronistic and irrational from a religious point of view, her religious identity is not less important than it is for the others. In order to safeguard the appropriate boundaries for her as a religious feminist, she maneuvers between estrangement and closeness, disgust and partnership, belonging and resignation. Her strategy is temporal and elliptic, without a center or a focus.

The 'interpreter' showed that religious feminism is the capacity to contain both points of view of the biblical text without deciding which one to accept or preferring the one over the other. The rationale behind this attitude is - the absence of blindness toward each side - neither towards feminism by revoking religion, nor towards religion by revoking feminism by way of apologetic justification of the unfairness of religion. It is difficult to decide whether the dualistic attitude of the interpreter is feminist or religious, and it might be more correct to define it as a religious feminist' attitude. As well, the 'Rabbanit', did not distinguish between the feminist and the religious identity. She wanted to pray regularly, to bless the candles on Friday evening, to say Kaddish of orphans out of a desire to achieve spiritual and personal elevation as an individual enjoying equal rights in society. In other words, for the 'rabbanit', as well as the 'interpreter', no distinction exists between her feminist and her religious identity; both of them are one and the same.

Thus, if the religious feminist identity, as reflected in the narratives, does not a conversion of the one with the other, religious feminism is not a mechanical connection, nor a combination of feminism and religion; the dialectic between feminism and religion expands the categories and creates a new theoretical category which is both feministic and religious as a shared space. This creation of identity does not fit the terminology of bridging the gap - 'adapting feminism to religion'; 'adapting religion to feminism' $(5,6,8,10,11,14)$. Instead, we should recognize the identity based on a meeting between religion and feminism is a dialectic identity with many options and ways of expression. It is neither feminist nor religious but a religious feminism with constant movement within religion and out of it, within feminism and out of it, with a constantly established identity within a social context. This point of view follows Butler's analysis, that proposes to depart from the binary of individual - society, man-woman, normal-deviant, and exchange it for a non-hierarchical point of view, that strives to understand the relativity of the self.

Foucaut (53) emphasizes the power of language as a structure of thought and discourse. We, as researchers and respondents, have difficulties in presenting findings out of words that do not exist. Such difficulties are apt to corroborate the notion that a religious feminist identity is vague, blurred and even broken, although the respondents were able to present a complete world view. The women of "Kolech" could tell us about many ways of acting, that break up religious rules and bypass the need to choose between feminism and religion or to decide on integration based on subjecting feminism to religion, or vice versa. They were religious feminists without a hyphen, without separation, not as a result of unification, adaptation or collapse of these areas. They cannot be placed in distinct categories, because of the 
emergence of a new category, that of the multiple religious feminist, complex and containing various shades traditional, resigned, interpreter, juggler and rabbinical. This identity enables us to attain a new perception of both feminism and orthodoxy and requires that we acknowledge the manifold relations between them. These relations derive from the basic conflict between feminism and religion (whether acknowledged or not) that suggests many challenges, strategies of action and ways of thinking to the women.

The story of the women interviewed in this study is about the interaction between identity, feminism and religion. It reflects the fact that identities and practices are not easily incorporated into structured categories, but rather challenge both the feminist and the religious discourses. The central theme of the research is the attempt to understand the influence of tradition (feminist and religious) on the definition of women's identity while they themselves experience innumerable new ways of understanding and experiencing it. The theoretical assumption of the research is that identity is not the grafting of two contradictory principles but a new framework containing a space for movement between contradictions and paradoxes.

Therefore we cannot regard the identity of the 'Kolech' women, as composed of two components, or otherwise, as an identity based on bridging mechanisms between the feminist and the orthodox dimensions. We are dealing with a new identity, the essence of which are the conflict and the difficulties in deciding (between alternatives) and searching for proper contexts, rather than a kind of anomaly; this is a continual process of creating an identity shifting between religion in feminist terms and feminism in religious terms, without the one dominating the other - religious feminism or feminist religion without inverted commas or a hyphen.

\section{Summing up}

This paper summarizes five religious feminist identities of women whom I interviewed. Nevertheless, the models are analytical and the boundaries are not dichotomous, and there is a spill-over in all directions in every one of the models, and one and the same woman can identify with more than one identity. In the choice of the identity model I attempted to expose the similarity between the women and also the difference between them and its sources. Religious feminism is not of one piece. The central theme that occupies every one of the women, like the unique solution to which she aspires, is a source of emphatic understanding of her and her world view.

\section{REFERENCES}

[1] Stanton EC. The woman's Bible. Mineola, NY: Dover Publications; 1993.

[2] Ali SR. Global feminist connections: Muslim feminist: An oxymoron. Woman View, Fall 2005:13-15.
[3] Ali SR, Mahmood A, Moel J, Hudson C, Leathers L. A qualitative investigation of Muslim and Christian women's views of religion and feminism in their lives. Cultural Diversity and Ethnic Minority Psychology 2008;14(1):38-46.

[4] Ammerman NT. Bible believers: Fundamentalists in the modern world. New Brunswick, NJ: Rutgers University Press; 1987.

[5] Ecklund EH. Catholic women negotiate feminism: A research note. Sociology of Religion 2003;64(4):515-524.

[6] Fine WW. Modern orthodox Judaism as an option for professional women. Journal of Jewish Communal Service 1995; 71(Winter/Spring):153-164.

[7] Gallagher SK, Smith C. Symbolic traditionalism and pragmatic egalitarianism Contemporary evangelicals, families, and gender. Gender Soc 1999;13(2):211-233.

[8] Manning C. God gave us the right: Conservative Catholic, evangelical Protestant, and Orthodox Jewish women grapple with feminism. New Brunswick, NJ: Rutgers University Press; 1999.

[9] Yadgar Y. Gender, religion, and feminism: The case of Jewish Israeli traditionalists. Journal for the Scientific Study of Religion 2006;45(3):353-370.

[10] Resnick Dufour L. Sifting through tradition: The creation of Jewish feminist identities. Journal for the Scientific Study of Religion 2000;39(1):90-106.

[11] Stocks J. To Stay or to Leave? Organizational legitimacy in the struggle for change among evangelical feminist. In: P. Edgell-Becker, N L Eiesland, editor. Contemporary American religion: An ethnographic reader Walnut Creek: Rowman Altamira; 1997. p. 99-118.

[12] Winter MT, Lummis AT, Stokes A. Defecting in place: Women claiming responsibility for their own spiritual lives. New-York: Crossroad Publishing Company; 1994.

[13] Calhoun CJ. Social theory and the politics of identity. In: Calhoun CJ, editor. Social Theory and Politics of Identity Cambridge, Mass: Blackwell; 1994. p. 9-36.

[14] Dillon M. Catholic identity: Balancing reason, faith, and power. Cambridge: Cambridge University Press; 1999.

[15] Plaskow J. Standing again at Sinai: Judaism from a feminist perspective. San Francisco: Harper \& Row; 1990.

[16] Brasher BE. Godly women: Fundamentalism and female power. New Brunswick: Rutgers University Press; 1998.

[17] Griffith RM. God's daughters: Evangelical women and the power of submission. Berkeley: Univ. of California Press; 1997.

[18] Collins PH. Black feminist thought: Knowledge, consciousness, and the politics of empowerment. Boston, Mass: Unwind Hyman; 1990.

[19] Kubicek K, McDavitt B, Carpineto J, Weiss G, Iverson EF, Kipke MD. "God Made Me Gay for a Reason" Young Men Who Have Sex With Men's Resiliency in Resolving Internalized Homophobia From Religious Sources. J Adolesc Res 2009;24(5):601-633.

[20] Neitz MJ. Charisma and Community: A Study of Religious Committment within the Charismatic Renewal. New 
Brunswick, NJ: Transaction Publishers; 1987.

[21] Ozorak EW. The power, but not the glory: How women empower themselves through religion. Journal for the Scientific Study of Religion 1996;35:17-29.

[22] Thumma S. Negotiating a religious identity: The case of the gay evangelical. Sociology of Religion 1991;52(4):333-347.

[23] Avishai O. "Doing Religion" In a Secular World Women in Conservative Religions and the Question of Agency. Gender Soc 2008;22(4):409-433.

[24] Chen C. A Self of One's Own Taiwanese Immigrant Women and Religious Conversion. Gender Soc 2005;19(3):336-357.

[25] Davidman L. Tradition in a rootless world: Women turn to Orthodox Judaism. Berkeley: Univ of California Press; 1991.

[26] Kaufman DR. Rachel's daughters: Newly orthodox Jewish women. . New Brunswick, NJ: Rutgers University Press; 1991.

[27] Longman C. "Not Us, but You Have Changed!" Discourses of Difference and Belonging among Haredi Women. Social compass 2007;54(1):77-95.

[28] Gallagher SK. Evangelical identity and gendered family life. . New Brunswick, NJ: Rutgers University Press; 2003.

[29] Pevey C, Williams CL, Ellison CG. Male God imagery and female submission: Lessons from a Southern Baptist ladies' Bible class. Qualitative Sociology 1996;19(2):173-193.

[30] Chong KH. Negotiating Patriarchy South Korean Evangelical Women and the Politics of Gender. Gender Soc 2006;20(6):697-724.

[31] Gallagher SK. Agency, Resources, and Identity Lower-Income Women's Experiences in Damascus. Gender Soc 2007;21(2):227-249.

[32] Hartman T, Marmon N. Lived regulations, systemic attributions menstrual separation and ritual immersion in the experience of Orthodox Jewish women. Gender Soc 2004;18(3):389-408

[33] Stacey J. Brave new families: Stories of domestic upheaval in late-twentieth-century America. New-York: Basic Books; 1990.

[34] Yanay N, Rapoport T. Ritual impurity and religious discourse on women and nationality. Women's Studies International Forum 1997;20(5):651-663.

[35] Gallagher SK. Where are the antifeminist evangelicals? Evangelical identity, subcultural location, and attitudes toward feminism. Gender Soc 2004;18(4):451-472.

[36] Gartner LP. History of the Jews in modern times. Oxford: Oxford University Press; 2001.

[37] Sagi, A., and Schwartz, D. editor. A Hundred Year of Religious Zionism: Figures and Thoughts. Ramat-Gan: Bar-Ilan University; 2003.

[38] Klatch R. Women of the New Right. Philadelphia: Temple University Press; 1987.

[39] Hunter JD. American evangelicalism: Conservative religion and the quandary of modernity. . New Brunswick, NJ: Rutgers University Press; 1983.
[40] Peshkin A. God's choice: The total world of a Christian fundamentalist school. Chicago: University of Chicago Press; 1986.

[41] Vigoda A. Simchat Torah - A Men's Festival? In: Margalit S, editor. To Be a Jewish Woman Jerusalem: Urim Publications; 2001. p. 198-201.

[42] El-Or T. Next Pessach: Literacy and identity of young religious Zionist women. ; 1998.

[43] Bernstein D. Women of the Western Wall and Other Prayer Groups. In: Margalit S, editor. To Be a Jewish woman Jerusalem: Urim Publications; 2001. p. 189-198.

[44] Friedman H. Teach Me My Lord to Bless and Pray: About a Women's Prayer Group. In: Tova C, editor. To Be a Jewish Woman Jerusalem: Graphit Press; 2009. p. 335-341.

[45] Hochstein-Goralin N. And Her Name in Israel Shall Be. In: Margalit S, editor. To Be a Jewish Woman Jerusalem: Urim Publications; 2001. p. 217-222.

[46] Levin Y. Women and Saying Kaddish On "Online Questions \& Answers". Amudim 2004;678(2-3):18-23.

[47] Lovitz R. Active Participation of Women in Funeral Ceremonies. In: Tova C, Aliza Lavie, editors. To Be a Jewish woman Jerusalem: Graphit Press Ltd; 2007. p. 357-380.

[48] Horev D. Who is My Sister? Voices of Mizrahi Religious Women in Religious Zionism and Their Place in Kolech.". In: Margalit Shilo, editor. To Be a Jewish Woman Jerusalem: Urim Publication; 2001. p. 326-338.

[49] Chase SE. Narrative inquiry: Multiple lenses, approaches, voice. In: Norman K. Denzin, Yvonna S. Lincoln, editors. The Sage handbook of qualitative research. 3 rd ed. Thousand Oaks, CA: Sage; 2005. p. 651-680.

[50] Lieblich A, Tuval-Mashiach R, Zilber T. Narrative research: Reading, analysis, and interpretation. : Sage; 1998.

[51] Rosental G. Reconsideration of Life Stories: Principles of Selection in Generating Stories for Narrative Bibliographical Interviews. In: L. Josselon. \& A. Lieblich, editor. The Narrative Study of Lives Washington: American Psychological Association; 1993. p. 59-91.

[52] Glaser B, Strauss A. The discovery grounded theory: strategies for qualitative inquiry. ; 1967.

[53] Foucault M. The order of things: An archaeology of the human sciences. New York: Routledge; 2001.

\footnotetext{
' Kolech, founded in 1998, is the first Orthodox Jewish feminist organization in Israel. Kolech aims to increase public awareness and bring change in Israeli society. It seeks to disseminate the values of gender equality and mutual respect, to encourage equal opportunity for women in the public arena, including the advancement of women's rights in religious halachic spheres. Kolech encourages greater equality for women in matters of personal status, such as marriage and divorce, and is in the forefront of an uncompromising battle against all forms of gender violence." http://www.kolech.org.il

ii The analysis focused on every interview separately. Every passage was regarded as a unit of significance and was described briefly. After completing the descriptions attached to the passages, I started to review the full interview and the story it contained from a structural point of view. With regard to every interview I asked what was the profile emerging from the answers of the respondent to every question: (1) what does she regard
} 
as religious feminism? (2) How did it develop in her mind? At this stage, different attitudes to religious feminism appeared among the respondents, but also some common features in the profiles that emerged. Accordingly, central common categories or themes were created, representing different options of religious feminism. After that, came another stage of meticulous analysis. All the interviews were read for the second time in order to obtain a more profound understanding of them: does the interview correspond to a certain profile of religious feminism? What characterizes the story and content of this interview and does it represent a new category of religious feminism? At this stage changes in the categories were made, some of the profiles were united and the final system of categories of religious feminism was established. 